\title{
THE DIALYSANCE OF ETHANOL AND METHANOL: A PRO- POSED METHOD FOR THE TREATMENT OF MASSIVE INTOXICATION BY ETHYL OR METHYL ALCOHOL *
}

\author{
By JULIEN MARC-AURELE $†$ AND GEORGE E. SCHREINER $\ddagger$
}

(From the Department of Medicine, Georgetown University School of Medicine and the Renal and Electrolyte Division, Georgetown University Hospital, Washington, D. C.)

(Submitted for publication November 5, 1959; accepted January 29, 1960)

Previous studies from this laboratory (1) have cited a time-dose-cytotoxic relationship and a high dialysance ${ }^{1}$ as important theoretical criteria for the selection of dialyzable poisons. Small molecular size, high solubility, clinical correlation with blood level and a primary distribution in the fluid phase of the body would suggest ethanol and methanol as ideal dialyzable toxins. Because of the time lag between ingestion of methanol and production of its lethal metabolites such as formic acid, early dialysis would seem critical in cases of methanol poisoning. Since each metabolite of methanol is more toxic, removal of the parent compound offers a unique leverage and constitutes preventive medicine as well as specific therapy.

\section{METHOD}

The dialysance of both alcohols was studied in vitro on the twin-coil artificial kidney ${ }^{2}$ using an $18 \mathrm{~L}$ reservoir which contained ethanol or methanol dissolved in plasma or normal saline. Since no inhibition of dialysance could be detected by the addition of protein, most experiments were conducted in saline. The solutions were circulated against a $100 \mathrm{~L}$ bath of fluid containing an equiosmolar concentration of solutes excluding the alcohol, at various flow rates measured at the venous end of the system by volume determinations of a timed collection. Once the coil was reasonably distended, out-

* This work was supported by a grant from the John A. Hartford Foundation.

$\dagger$ Research Fellow in Medicine; Research Fellow, National Heart Foundation of Canada.

¥Associate Professor of Medicine; Director, Renal and Electrolyte Division.

${ }^{1} \mathrm{D}=\mathrm{a} \frac{\mathrm{A}-\mathrm{V}}{\mathrm{A}-\mathrm{B}}$ in which $\mathrm{D}=$ dialysance (milliliters per minute), $\mathrm{a}=$ flow rate (milliliters per minute), $\mathrm{A}=$ arterial concentration (e.g., milligrams per $100 \mathrm{ml}$ ), $\mathrm{V}=$ venous concentration (e.g., milligrams per $100 \mathrm{ml}$ ), B = bath concentration (e.g., milligrams per $100 \mathrm{ml}$ ). This relates "clearance" in the artificial kidney to the flow rate, the arteriovenous difference across the dialyzer, and the bloodbath concentration gradient.

${ }^{2}$ Supplied by 'Travenol Laboratories, Morton Grove, flow pressure (measured from the bubble catcher) was maintained constantly at zero. An interval of one circulation time was allowed between arterial and venous samplings, while bath samplings took place half-way between the two measurements.

In vivo experiments were carried out on 11 female mongrel dogs ranging in weight from 13.1 to $27.2 \mathrm{~kg}$. Absolute spirits in doses of 3.2 to $6 \mathrm{ml}$ per $\mathrm{kg}$ were infused intravenously as a 20 per cent solution in saline over a period of 30 to 60 minutes. Each set of experiments included 3 animals given equal amounts of alcohol; 2 of them were observed as controls against a third animal submitted to hemodialysis. One experiment was conducted with a single control.

Extracorporeal circulation was established from the left femoral artery through a single coil of the conventional twin-coil dialyzer and returned to the animal via the adjacent femoral vein. A solution of 6 per cent dextran and 10 per cent invert sugar in saline was used to prime the machine. The right femoral artery was also cannulated and connected to a mercury manometer. thus permitting continuous visualization of the mean blood pressure and arterial pulsation. Each dog was dialyzed for 3 hours at an average flow rate of $150 \mathrm{ml}$ per minute. The volume of the bath fluid was arbitrarily fixed at $50 \mathrm{~L}$ in the ethanol experiments and at $100 \mathrm{~L}$ in the cases of methanol-poisoned animals; its composition was as usually made for clinical dialysis and the temperature was kept constant at $39^{\circ} \mathrm{C}$.

Chemical determinations of ethyl alcohol were done by reduction of acid potassium dichromate according to the method described by Kingsley and Current (2). This technique in our hands yielded recoveries ranging from 95.6 to 101 per cent. The same reaction applied to aqueous solutions of methanol showed a strict accordance to the Lambert-Beer's law and a comparable degree of accuracy in recovery experiments. Thus, our dealing with one alcohol at a time in the in vitro experiments prevented any cumulative reducing effect and permitted the use of the same method for the quantification of methanol. However, because of the possible occurrence of interfering substances in biological material, analyses of plasma methanol were done by a specific microdiffusion technique using potassium carbonate as a liberating agent and potassium permanganate and chromotropic acid as reagents (3). Prior to analysis, all the plasma samples were found negative on testing for acetone and formaldehyde. 
TABLE I

In vitro dialysis of ethanol

\begin{tabular}{|c|c|c|c|c|c|c|}
\hline $\begin{array}{l}\text { Coil } \\
\text { no. }\end{array}$ & $\begin{array}{l}\text { Flow } \\
\text { rate }\end{array}$ & $\begin{array}{l}\text { Inflow } \\
\text { conc. }\end{array}$ & $\begin{array}{l}\text { Outflow } \\
\text { conc. }\end{array}$ & $\begin{array}{l}\text { Bath } \\
\text { conc. }\end{array}$ & $A-V^{*}$ & Dialysance \\
\hline \multirow{4}{*}{1} & $m l / \min$ & $m g / 100 \mathrm{ml}$ & $\mathrm{mg} / 100 \mathrm{ml}$ & $\mathrm{mg} / 100 \mathrm{ml}$ & $\mathrm{mg} / 100 \mathrm{ml}$ & $m l / \min$ \\
\hline & 306 & 682 & 368 & 145 & 314 & 178 \\
\hline & 134 & 464 & 304 & 201 & 160 & 81 \\
\hline & 66 & 360 & 252 & 219 & 108 & 51 \\
\hline \multirow{3}{*}{2} & 483 & 712 & 450 & 42 & 262 & 188 \\
\hline & 368 & 321 & 235 & 89 & 86 & 136 \\
\hline & 251 & 229 & 166 & 86 & 63 & 110 \\
\hline \multirow[t]{4}{*}{3} & 342 & 561 & 362 & 20 & 199 & 125 \\
\hline & 246 & 434 & 228 & 26 & 206 & 124 \\
\hline & 152 & 590 & 180 & 45 & 410 & 114 \\
\hline & 100 & 419 & 145 & 85 & 274 & 82 \\
\hline \multirow[t]{3}{*}{4} & 507 & 439 & 304 & 32 & 135 & 167 \\
\hline & 300 & 394 & 211 & 35 & 183 & 152 \\
\hline & 210 & 319 & 139 & 66 & 180 & 149 \\
\hline \multirow[t]{2}{*}{ - } & 120 & 302 & 96 & 84 & 205 & 95 \\
\hline & 70 & 247 & 76 & 66 & 170 & 66 \\
\hline \multirow[t]{5}{*}{5} & 470 & 492 & 366 & 62 & 126 & 138 \\
\hline & 294 & 421 & 248 & 81 & 173 & 149 \\
\hline & 228 & 356 & 181 & 86 & 175 & 142 \\
\hline & 111 & 356 & 131 & 103 & 225 & 99 \\
\hline & 55 & 271 & 105 & 82 & 166 & 48 \\
\hline \multirow[t]{3}{*}{6} & 480 & 628 & 422 & 60 & 206 & 174 \\
\hline & 438 & 508 & 384 & 79 & 124 & 127 \\
\hline & 393 & 462 & 332 & 94 & 130 & 139 \\
\hline
\end{tabular}

* Arteriovenous difference across the artificial kidney obtained by subtracting the outflow concentration from the inflow concentration.

The dialysance was calculated by the formula of Wolf, Remp, Kiley and Currie (4), as shown in Footnote 1 .

\section{RESULTS}

The results of the in vitro dialyses are presented in Tables I and II.
The dialysance of ethanol has been determined over a selected range of flow rates from 55 to 507 $\mathrm{ml}$ per minute. The experimental values obtained ranged between 48 and $188 \mathrm{ml}$ per minute. Their relationship is shown graphically on Figure 1. A steep elevation of the dialysance is apparent with flow rates increasing to a value in the vicinity

TABLE II

In vitro dialysis of methanol.

\begin{tabular}{|c|c|c|c|c|c|c|}
\hline $\begin{array}{l}\text { Coil } \\
\text { no. }\end{array}$ & $\begin{array}{l}\text { Flow } \\
\text { rate }\end{array}$ & $\begin{array}{l}\text { Inflow } \\
\text { conc. }\end{array}$ & $\begin{array}{l}\text { Outflow } \\
\text { conc. }\end{array}$ & $\begin{array}{l}\text { Bath } \\
\text { conc. }\end{array}$ & $A-V^{*}$ & Dialysance \\
\hline \multirow{6}{*}{1} & $\mathrm{ml} / \min$ & $\mathrm{mg} / 100 \mathrm{ml}$ & $\mathrm{mg} / 100 \mathrm{ml}$ & $\mathrm{mg} / 100 \mathrm{ml}$ & $\mathrm{mg} / 100 \mathrm{ml}$ & $m l / \min$ \\
\hline & 528 & 324 & 229 & 14 & 95 & 162 \\
\hline & 418 & 256 & 181 & 20 & 75 & 133 \\
\hline & 329 & 237 & $\begin{array}{l}101 \\
134\end{array}$ & 23 & 103 & 158 \\
\hline & 182 & 216 & $\begin{array}{r}104 \\
93\end{array}$ & 33 & 123 & 122 \\
\hline & $\begin{array}{r}102 \\
98\end{array}$ & $\begin{array}{l}210 \\
192\end{array}$ & 66 & $\begin{array}{l}35 \\
35\end{array}$ & 126 & 79 \\
\hline \multirow[t]{3}{*}{2} & 384 & 278 & 176 & 22 & 102 & 153 \\
\hline & $\begin{array}{l}304 \\
146\end{array}$ & $\begin{array}{l}270 \\
184\end{array}$ & 84 & $\begin{array}{l}22 \\
33\end{array}$ & 100 & 96 \\
\hline & 84 & 150 & $\begin{array}{l}07 \\
38\end{array}$ & 39 & 112 & 84 \\
\hline \multirow[t]{5}{*}{3} & 439 & 394 & 235 & 19 & 159 & 186 \\
\hline & 370 & 318 & 181 & 26 & 137 & 174 \\
\hline & 310 & 262 & 148 & 40 & 114 & 159 \\
\hline & 230 & 208 & 116 & 46 & 92 & 130 \\
\hline & 64 & 183 & 58 & 53 & 125 & 62 \\
\hline \multirow[t]{5}{*}{4} & 475 & 350 & 220 & 27 & 130 & 191 \\
\hline & 413 & 290 & 178 & 36 & 112 & 182 \\
\hline & 360 & 232 & 154 & 46 & 78 & 151 \\
\hline & 268 & 184 & 111 & 52 & 73 & 148 \\
\hline & 79 & 158 & 67 & 60 & 91 & 73 \\
\hline
\end{tabular}

* See footnote to Table I. 


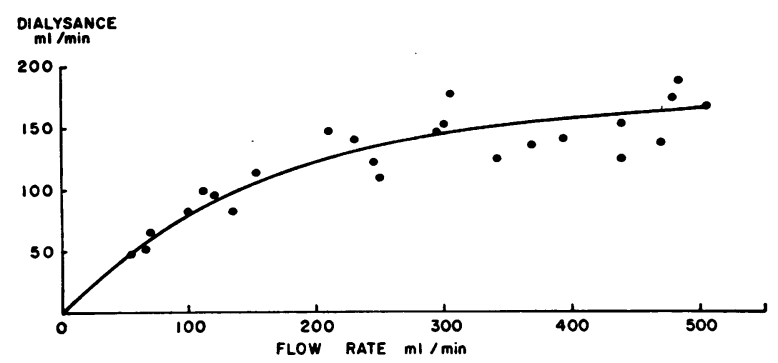

Fig. 1. Dialysance of ethanol in Vitro.

of $225 \mathrm{ml}$ per minute. Further increase of the flow, however, affected the removal of alcohol to a much lesser extent.

Similar results were obtained when dialyzing methanol at flow rates varying from 64 to $528 \mathrm{ml}$ per minute. The dialysance of this compound ranged between 62 and $191 \mathrm{ml}$ per minute and behaved in a comparable fashion with progressive elevation of the flow rate (Figure 2).

These data illustrate clearly the similarity of transfer of ethyl and methyl alcohol across the dialyzing membrane. The high dialysance of the two compounds compares favorably with that of urea as measured under similar conditions in the twin-coil kidney by Kolff and Watschinger (5) and Schreiner, Maher and Marc-Aurele (6) as well as that obtained from human dialyses by Meyer (7). Comparison with other non-ionized substances (6) revealed that at a flow rate of 200 $\mathrm{ml}$ per minute, the clearance of ethanol or methanol approximated 1.5 times that of uric acid, 1.2 times that of creatinine and 1.7 times that of phenobarbital.

Typical results obtained from in vivo experiments are illustrated in Figures 3 and 4. For simplicity of presentation, the plasma alcohol curve of only one control animal has been plotted in each graph. The data pertinent to each period of hemodialysis are summarized in Table III.

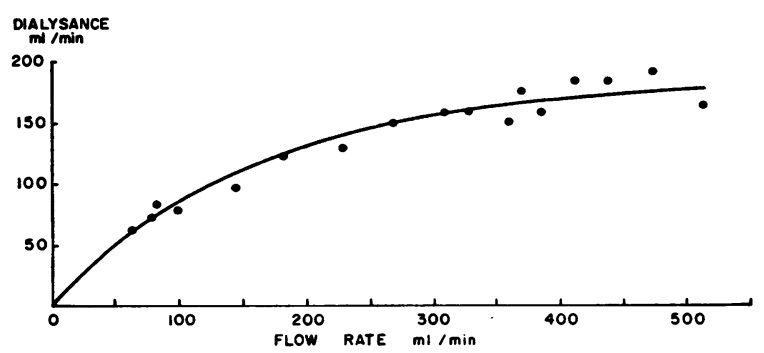

Fig. 2. Dialysance of methanol in Vitro.

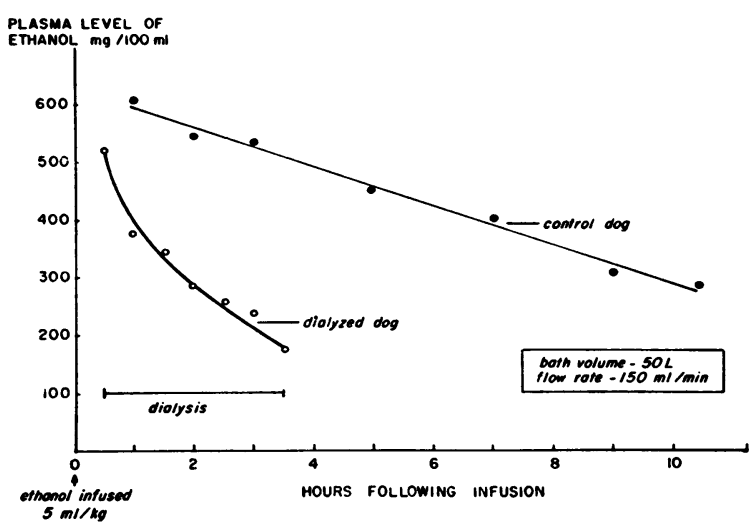

Fig. 3. EFFect of hemodialysis on ACUTE ETHANOL INTOXICATION IN DOGS.

Figure 3 shows the plasma alcohol concentrations of two dogs infused with $5 \mathrm{ml}$ per $\mathrm{kg}$ of absolute ethanol. The spontaneous decline of the plasma ethanol levels in the control animal was from 605 to $282 \mathrm{mg}$ per $100 \mathrm{ml}$ over a period of 10.5 hours. Three hours of hemodialysis lowered the plasma concentration of the other animal from 519 to $178 \mathrm{mg}$ per $100 \mathrm{ml}$. Comparable results were obtained from another set of animals given $6 \mathrm{ml}$ per $\mathrm{kg}$ of absolute ethanol (Table III).

Because of the slower metabolism of methyl alcohol, dogs poisoned with this compound were observed over a period of 48 hours. Figure 4 exemplifies the capability of the artificial kidney in removing methanol from an animal which had been given $5 \mathrm{ml}$ per $\mathrm{kg}$ of the absolute compound. By the end of the third hour of the procedure, the dialyzed dog had its plasma concentration de-

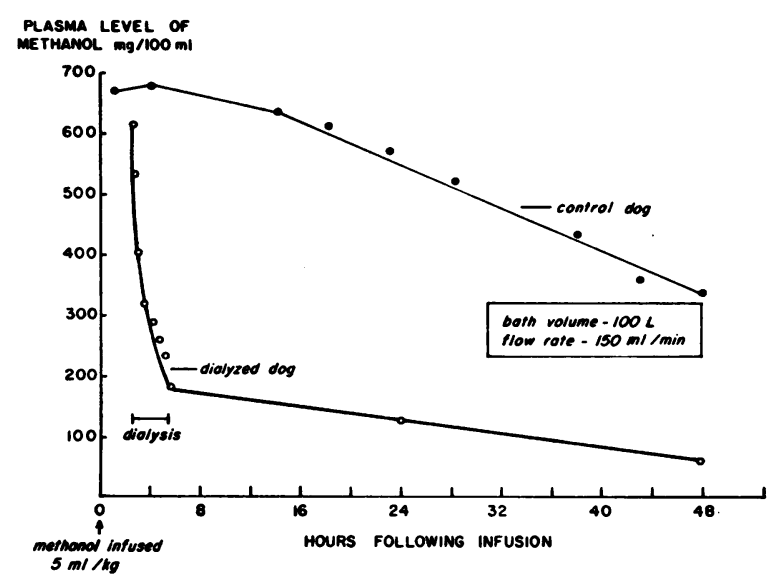

Fig. 4. EFFECT of hemodialysis on ACUTE METHANOL. INTOXICATION IN DOGS. 
creased from 615 to $180 \mathrm{mg}$ per $100 \mathrm{ml}$. This contrasted with the control dog which still had a plasma level of $343 \mathrm{mg}$ per $100 \mathrm{ml}$ two days after the infusion. A similar contrast appears when comparing the data obtained from two other animals studied under identical conditions (Table III).

With two exceptions, each control was given the same amount of alcohol per unit of weight as its dialyzed partner (Table III). The efficiency of hemodialyses is thus reflected from a comparison of their respective hourly fall of plasma alcohol expressed in percentage of the initial level shown on the graphs. Such calculations disclosed that in the actual conditions, the artificial procedure was 4.2, 4.3 and 3.8 times faster than the physiological removal of ethanol by the control animals. In the cases of methanol poisoning the comparative efficiencies were 22 and 16 times that of the controls. Identical results from different sets of experiments can hardly be expected, considering the individual variations of the rate of metabolism of alcohol (8) as well as the individuality in coil performance (9). Further increase in the amount dialyzed would have been achieved with a higher flow rate or by changing the bath solution at the middle of each run (4).

The amount of ethanol recovered in the bath at the end of each in vivo dialysis was 29 and 33 per cent of the administered doses. Values of 25 and 27 per cent were found for methanol. This, however, represents strictly minimum recoveries, since no correction could be induced for the substantial loss of alcohol evaporated from the surface of the baths heated to $39^{\circ} \mathrm{C}$.

Under clinical observations, all the ethanol control animals remained unconscious and unresponsive during the ten hours of study, in contrast to the dialyzed dogs which awoke by the second hour of the procedure.

Methanol-poisoned controls xhibited inability to stand on their feet for 24 hours and had a very ataxic gait for some 36 hours following the infusion. They all developed blindness with severe papillitis and retinal edema which subsided a few days later. Slight hyperemia of the optic disc was observed in one of the dialyzed animals, but blindness was never apparent in the dialyzed

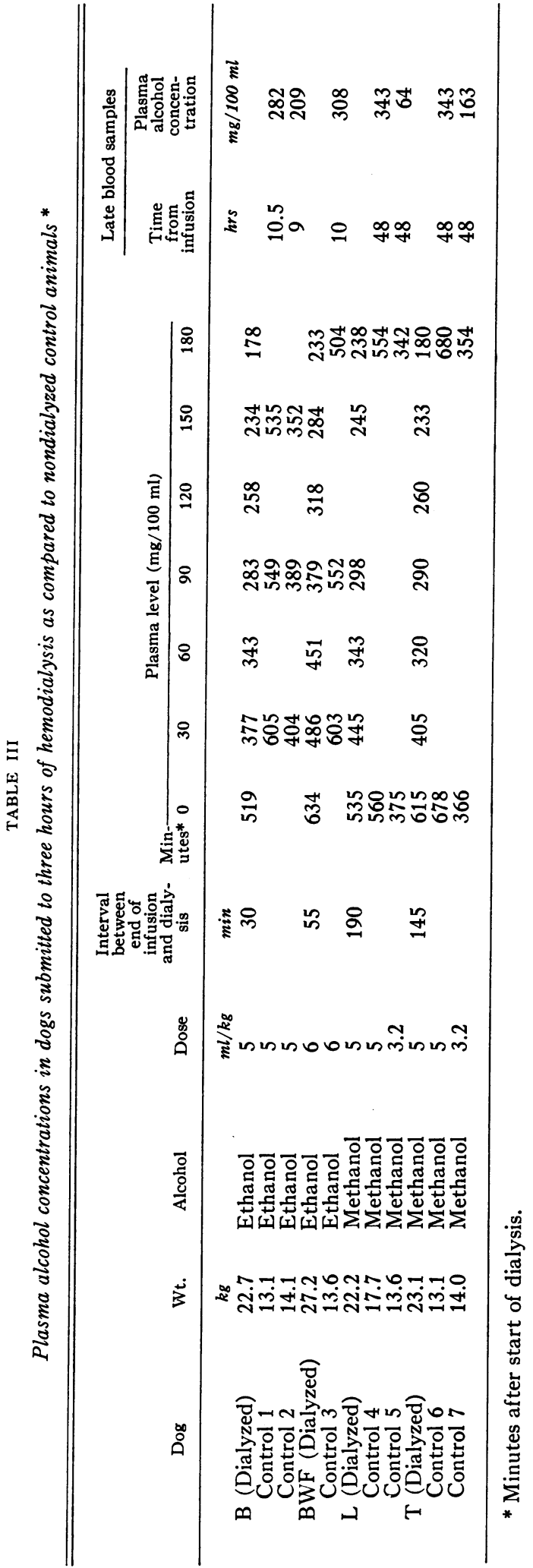


animals and both of them were alert at the end of the procedure.

\section{DISCUSSION}

More than 1,000 deaths are reported each year in the United States from acute alcohol poisoning (10). Massachusetts alone reported 4,505 deaths from ethyl alcohol and 118 from other alcohols in the period from 1928 through 1937. In a series reported from the Boston City Hospital (11), 59 per cent of all patients admitted in coma were suffering from severe alcoholic intoxication. The relationship of alcohol blood levels to clinical symptoms is succinctly outlined by Victor and Adams (12), who also give a good account of the history of alcohol poisoning. The metabolism and toxicity of methanol have been reviewed by $\mathrm{R} \phi \mathrm{e}$ (13).

Methanol poisoning usually occurs in group outbreaks in young individuals (14-17), but methanol may even be poisonous by inhalation $(18,19)$. In addition to the danger of death, severe ocular damage represents a tragic form of late morbidity $(20,21)$.

Treatment of these poisonings has to date been symptomatic and supportive. Delineation of the criteria for dialyzability of circulating poisons (1) led us to postulate that ethanol and methanol would represent practical substances for dialytic removal. The present study represents experimental verification of these considerations. In vitro experiments show clearly the rapid removal rate of both alcohols. In vivo experiments confirm the high dialysance from biological solutions and demonstrate the ability to prevent or reverse coma.

Preliminary studies with $\mathrm{C}^{\mathbf{1 4}}$-labeled ethanol permitted simultaneous measurement of both alcohols and do not suggest any depressing effect of one upon the dialysance of the other. It would thus be rational and safe to use ethanol to block the metabolism of methanol in a poisoned patient. Since the metabolites of methanol are said to be 6 and 30 times as toxic as the parent compound (17), early dialysis provides a unique opportunity for preventive medicine. No direct measurements of formic acid or formaldehyde were made, but they too should be theoretically dialyzable.

\section{SUM MARY}

The dialysances of ethyl and methyl alcohol have been measured in vitro.

Data from experiments on dogs poisoned with ethanol or methanol have been presented. These provide a rational basis for the use of this technique in massive ethanol or methanol intoxications which are major clinical causes of personal and epidemic poisonings.

Emphasis is placed on the importance of early action with the artificial kidney in the treatment of acute poisoning.

\section{ACKNOWLEDGMENTS}

The authors acknowledge with pleasure the assistance of Dr. Israel Posner and Moira Maclean, R.N.

\section{REFERENCES}

1. Schreiner, G. E. The role of hemodialysis (artificial kidney) in acute poisoning. A.M.A. Arch. intern. Med. 1958, 102, 896.

2. Kingsley, G. R., and Current, H. Simple spectrophotometric determination of ethanol in blood by diffusion in an autoclave. J. Lab. clin. Med. 1950, 35, 294.

3. Feldstein, M., and Klendshoj, N. C. The determinations of methanol and isopropanol in biological fluids by microdiffusion analysis. Canad. J. med. Tech. 1954, 16, 135.

4. Wolf, A. V., Remp, D. G., Kiley, J. E., and Currie, G. D. Artificial kidney function: Kinetics of hemodialysis. J. clin. Invest. 1951, 30, 1062.

5. Kolff, W. J., and Watschinger, B. Further development of a coil kidney. Disposable artificial kidney. J. Lab. clin. Med. 1956, 47, 969.

6. Schreiner, G. E., Maher, J. F., and Marc-Aurele, J. The dialysance of exogenous poisons and some common metabolites in the twin-coil artificial kidney (abstract). J. clin. Invest. 1959, 38, 1040.

7. Meyer, R., Straffon, R. A., Rees, S. B., Guild, W. R., and Merrill, J. P. A laboratory and clinical evaluation of the Kolff coil kidney. J. Lab. clin. Med. 1958, 51, 715 .

8. Newman, H. W and Cutting, W. C. Alcohol injected intravenously: Rate of disappearance from the blood stream in man. J. Pharmacol. exp. Ther. 1935, 54, 371.

9. Maher, J. F. Schreiner, G. E., and Marc-Aurele, J. Methodologic problems associated with in vitro measurements of dialysance. Trans. Amer. Soc. artif. Intern. Organs 1959, 5, 120.

10. Vital Statistics of the United States. Washington, D.C., Government Printing Office, 1958-1959, vol. 2, Tables 59 and 61 . 
11. Solomon, P., and Aring, C. D. The causes of coma in patients entering a general hospital. Amer. J. med. Sci. 1934, 188, 805.

12. Victor, M., and Adams, R. D. Effect of alcohol on the nervous system. Ass. Res. nerv. Dis. Proc. 1953, 32, 526.

13. Rфe, O. The metabolism and toxicity of methanol. Pharmacol. Rev. 1955, 7, 399.

14. Jacobson, B. M., Russel, H. K., Grimm, J. J., and Fox, E. C. Acute methyl alcohol poisoning. U. S. nav. med. Bull. 1945, 44, 1099.

15. Kaplan, A., and Levreault, G. V. Methyl alcohol poisoning: Report of 42 cases. U. S. nav. med. Bull. 1945, 44, 1107.

16. Bennett, I. L., Jr., Cary, F. H., Mitchell, G. L., Jr., and Cooper, M. N. Acute methyl alcohol poisoning. A review based on experiences in an out- break of 323 cases. Medicine (Baltimore) 1953, 32, 431.

17. Keeney, A. H., and Mellinkoff, S. M. Methyl alcohol poisoning. Ann. intern. Med. 1951, 34, 331.

18. Skinner, J. B. Toxic hazards. Methanol. New Engl. J. Med. 1957, 257, 1242.

19. Sayers, R. R., Yant, W. P., Schrenk, H. H., Chornyak, J., Pearce, J. J., Patty, F. A., and Linn, J. G. Methanol poisoning. J. industr. Hyg. 1944, 26, 255.

20. Gilger, A. P., and Potts, A. M. Studies on the visual toxicity of methanol. Amer. J. Ophthal. 1955, 39, 63.

21. Røe, O. Clinical investigations of methyl alcohol poisoning with special reference to the pathogenesis and treatment of amblyopia. Acta med. scand. 1943, 113, 558. 